\title{
Modified RMR to determine rock mass quality, study case of diversion tunnel in Meninting Dam, West Nusa Tenggara, Indonesia
}

\author{
Brilyan Jati Wijaya ${ }^{1,2}$, I Wayan Warmada ${ }^{1 *}$, and I Gde Budi Indrawan ${ }^{1}$ \\ ${ }^{1}$ Departement of Geological Engineering, Gadjah Mada University, Yogyakarta, Indonesia \\ ${ }^{2}$ Regional Infrastructure Development Agency, Ministry of Public Works and Housing, Indonesia
}

\begin{abstract}
The Meninting Dam under construction on Lombok Island, West Nusa Tenggara, Indonesia, requires a good planning to build a diversion tunnel to support its development and mobilization. The diversion tunnel is planned to be built through rocks with medium to poor rock mass quality. The planning stage involves various parameters, i.e., the rock mass classification, using either the RMR or GSI method. Converting values from one method to another makes planning work easier. However, the constraints found were the limitations of the observational data, such as discontinuity conditions. The objective of this article is to discuss the alternative depiction of discontinuity conditions in rock mass using RMR method. An alternative equation was developed to obtain a prediction model for determining the RMR value, based on GSI data. The evaluation showed that the mathematical models developed in this research had a small gap of error compared to other values. The models then can be used to predict RMR value based on GSI data and vice versa, with a higher degree of accuracy and precision according to the actual rock surface conditions, especially in the construction site of diversion tunnel at Meninting Dam.
\end{abstract}

\section{Introduction}

The construction of a dam is intended to optimize water resource utilization and to reduce flood disasters in rural areas. When building a dam, there is a stage to divert river or water flow. The deflection of that water flow is aimed to create dry conditions for constructing the main dam and support the mobilization of heavy equipment and building materials.

In conducting diversion of the river, BWS Nusa Tenggara I, as the stakeholder, utilizes a diversion tunnel. The diversion tunnel at the Meninting Dam is being built through rock units of pyroclastic breccias and lapilli tuff as shown on the geological regional map by Mangga et al [1]. Wiyasri [2] in 2020 stated that rock mass quality in that site had fair to poor rock mass quality as shown in Fig.2. The rock mass quality at the construction site had been determined using RMR method. Comparable values need to be calculated to describe and to ensure the rock mass quality, since RMR could not provide some results for complex computation i.e., failure criterion [3]. One of the methods which can be used to determine rock mass quality is GSI method. GSI offers simplicity in determining rock mass quality, as it based on qualitative observation. But problems were found when correlating RMR and GSI, some sub parameters which used in RMR were reduced in GSI, and they made the degree of accuracy and precision

\footnotetext{
*Corresponding author: warmada@ugm.ac.id
}

declined. Thus, a model needs to be developed to close the gap and to make the correlation model more reliable.

\subsection{RMR}

Rock Mass Rating (RMR) is a method used to classify the quality of rock mass. $\mathrm{RMR}_{89}$ was first developed by Bieniawski [4] in 1973-1989 and continues to be developed until the recent years. RMR is a method to determine rock mass quality by combining qualitative and quantitative observations. In $\mathrm{RMR}_{89}$, there are 5 parameters used to determine the quality of rock mass, as shown on Table 1, they are the number of unconfined compressive strength, the amount of Rock Quality Designation (RQD), spacing of discontinuities, discontinuities condition, and the presence of groundwater, each of them then categorized into $R_{1}, R_{2}$, $\mathrm{R}_{3}, \mathrm{R}_{4}$, and $\mathrm{R}_{5}$.

The condition of the discontinuities (then called $\mathrm{R}_{4}$ ) consists of several sub-parameters, including the length of the discontinuities (persistence), the aperture of the discontinuities, the condition of the gap filling material, the degree of roughness, and weathering. Then $\mathrm{RMR}_{89}$ value is summarized from each rating of $R_{1}$ to $R_{5}$. In its development, $\mathrm{RMR}_{89}$ also adopts $\mathrm{R}_{6}$, where this parameter describes the effect of discontinuities orientation. The weight of the parameter $\mathrm{R}_{6}$ is from to below zero, considering that the discontinuities orientation tends to disserve the rock mass quality. 
Table 1. A set of parameters of RMR89.

\begin{tabular}{|c|c|c|c|c|c|c|c|c|c|}
\hline \multirow{3}{*}{$\begin{array}{l}\text { No } \\
\\
1\end{array}$} & \multirow{3}{*}{$\begin{array}{l}\text { Parameter } \\
\text { Strength of } \\
\text { intact rock } \\
\text { material }\end{array}$} & \multirow{3}{*}{$\begin{array}{l}\text { Point load strength } \\
\text { index (MPa) } \\
\text { UCS (Mpa) }\end{array}$} & \multicolumn{7}{|c|}{ Range Values } \\
\hline & & & \multirow{2}{*}{$\begin{array}{l}>10 \\
>250\end{array}$} & \multirow{2}{*}{$\begin{array}{l}4-10 \\
100-250\end{array}$} & \multirow{2}{*}{$\begin{array}{l}2-4 \\
50-100\end{array}$} & \multirow{2}{*}{$\begin{array}{l}1-2 \\
25-50\end{array}$} & \multicolumn{3}{|c|}{$\begin{array}{l}\text { For this low range, } \\
\text { uniaxial } \\
\text { compressive test is } \\
\text { preferred }\end{array}$} \\
\hline & & & & & & & $5-25$ & $1-5$ & $<1$ \\
\hline & Rating & & 15 & 12 & 7 & 4 & 2 & 1 & 0 \\
\hline \multirow{2}{*}{2} & \multicolumn{2}{|l|}{ RQD (\%) } & $90-100$ & $75-90$ & $50-75$ & $25-50$ & \multicolumn{3}{|l|}{$<25$} \\
\hline & \multicolumn{2}{|l|}{ Rating } & 20 & 17 & 13 & 8 & \multicolumn{3}{|l|}{3} \\
\hline \multirow{2}{*}{3} & \multicolumn{2}{|c|}{ Spacing of discontinuities } & $>2 \mathrm{~m}$ & $0.6-2 \mathrm{~m}$ & $200-600 \mathrm{~mm}$ & $<60 \mathrm{~mm}$ & \multirow{2}{*}{\multicolumn{3}{|c|}{5}} \\
\hline & \multicolumn{2}{|l|}{ Rating } & 20 & 15 & 10 & 8 & & & \\
\hline \multirow{10}{*}{4} & \multirow{10}{*}{$\begin{array}{l}\text { Condition of } \\
\text { Discontinuities }\end{array}$} & Persistence & $<1 \mathrm{~m}$ & $1-3 \mathrm{~m}$ & $3-10 m$ & $10-20 \mathrm{~m}$ & \multicolumn{3}{|c|}{$>20 \mathrm{~m}$} \\
\hline & & Rating & 6 & 4 & 2 & 1 & \multicolumn{3}{|l|}{0} \\
\hline & & Aperture & None & $<0.1 \mathrm{~mm}$ & $0.1-1 \mathrm{~mm}$ & $1-5 \mathrm{~mm}$ & \multicolumn{3}{|c|}{$>5 \mathrm{~mm}$} \\
\hline & & Rating & 6 & 5 & 4 & 1 & \multicolumn{3}{|l|}{0} \\
\hline & & $\begin{array}{l}\text { Degree of } \\
\text { Roughness }\end{array}$ & Very rough & Rough & Slightly rough & Smooth & \multicolumn{3}{|c|}{ Very smooth } \\
\hline & & Rating & 6 & 5 & 3 & 2 & \multicolumn{3}{|l|}{0} \\
\hline & & Infilling & None & $\begin{array}{l}\text { Hard }<5 \\
\mathrm{~mm}\end{array}$ & Hard $>5 \mathrm{~mm}$ & $\begin{array}{l}\text { Soft }<5 \\
\mathrm{~mm}\end{array}$ & \multicolumn{3}{|c|}{ Soft $>5 \mathrm{~mm}$} \\
\hline & & Rating & 6 & 4 & 2 & 2 & \multicolumn{3}{|l|}{0} \\
\hline & & $\begin{array}{l}\text { Degree of } \\
\text { Weathering }\end{array}$ & Fresh & $\begin{array}{l}\text { Slightly } \\
\text { weathered }\end{array}$ & $\begin{array}{l}\text { Moderately } \\
\text { weathered }\end{array}$ & $\begin{array}{l}\text { Highly } \\
\text { weathered }\end{array}$ & \multicolumn{3}{|c|}{$\begin{array}{l}\text { Completely } \\
\text { weathered }\end{array}$} \\
\hline & & Rating & 6 & 5 & 3 & 1 & \multicolumn{3}{|l|}{0} \\
\hline \multirow[t]{3}{*}{5} & \multirow[t]{3}{*}{ Groundwater } & $\begin{array}{l}\text { Inflow per } 10 \mathrm{~m} \\
\text { tunnel length } \\
\text { Ratio: joint water } \\
\text { pressure/major } \\
\text { principal stress }\end{array}$ & None & $<0.1$ & $0.1-0.2$ & $25-125$ & \multicolumn{3}{|l|}{$>0.5$} \\
\hline & & $\begin{array}{l}\text { General } \\
\text { conditions }\end{array}$ & $\begin{array}{l}\text { Completely } \\
\text { dry }\end{array}$ & Damp & Wet & Dripping & Flowi & & \\
\hline & & Rating & 15 & 10 & 7 & 4 & 0 & & \\
\hline
\end{tabular}

\section{$1.2 \mathrm{GSI}$}

In the rock mechanics, Hoek-Brown failure criterion often utilized to determine rock mass deformation. The Hoek-Brown [3] failure criterion uses several input parameters which some can be obtained from RMR. However, the values of those parameters derived from RMR observations did not work well on rock with very poor quality, since then Hoek [5] stated that minimum value of $\mathrm{RMR}_{89}$ is 23. Thus, in the following years Hoek and Brown [6] developed a rock mass quality classification method called GSI. GSI (Geological Strength Index) is a method to determine rock mass quality based on visual observations and it is qualitative, as stated by Sonmez and Ulusay [7]. Fig. 1 shows the chart used to interpret rock mass quality. In principle, the determination of rock mass quality using GSI method is carried out by observing the surface and the structural conditions on the rock surface, as stated by Sonmez and Ulusay [8].

Before correlating GSI and $\mathrm{RMR}_{89}$, a conceptual comparison of the use of both methods is carried out as follows.

\subsection{Parameters}

Ceballos et al [9] compared the parameters used in classifying rock mass quality, both in $\mathrm{RMR}_{89}$ and GSI as shown in the Table 2 below. In $\mathrm{RMR}_{89}$, there are 5 parameters in minimal that used to determine the rock mass quality (excluding orientation of discontinuities). Each parameter in the RMR has its own weight, with a total value of 100. Meanwhile in GSI, the determination of rock mass quality is worked qualitatively by 
observing the condition of the very rock mass structure and the condition of the rock surface, where those two parameters can be considered to have the same weight.

Table 2. Parameter used in GSI and RMR 89

\begin{tabular}{ccc}
\hline \multirow{2}{*}{ Parameter } & \multicolumn{2}{c}{ Weight } \\
\cline { 2 - 3 } & RMR & GSI \\
\hline UCS & 15 & 0 \\
\hline Structure of Rock Mass & 40 & 50 \\
\hline Condition of Discontinuities & 30 & 50 \\
\hline Presence of Water & 15 & 0 \\
\hline
\end{tabular}

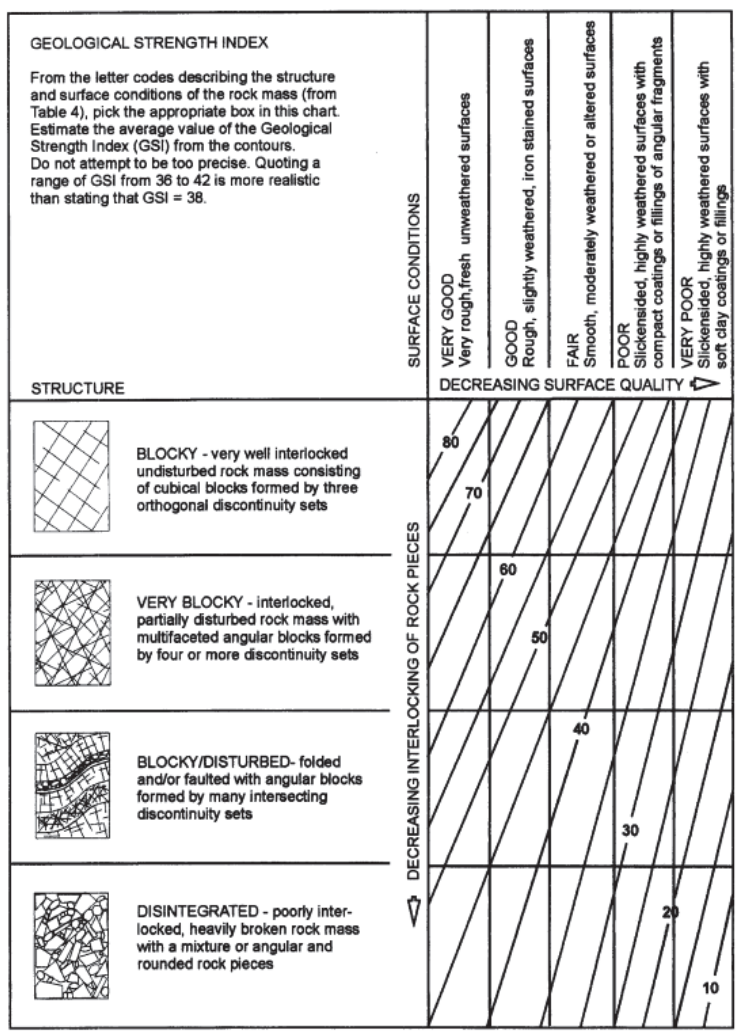

Fig. 1. Chart of GSI that used for determining rock mass quality.

Apart from the parameters, the two methods above are also distinguished by their intended use. RMR was created and developed to determine the quality of the rock mass as a matter for tunnel planning. Some of tunnel planning using this method for deciding the excavation method, supporting, standing time analysis, and tunnel lining calculation.

Meanwhile, GSI was developed to determine the value of rock mass quality in more simpler ways. Then value of that process is usually used to determine geotechnical calculations, such as deformation analysis and shear strength, as stated by Ceballos et al [9].

\subsection{Objectives}

Based on GSI and RMR values that had been obtained from direct observation, a model can be developed to correlate them both. Some correlation models had been developed on the previous research and can be used to show the adjacency between each other's. Then, to convert the values from a method to another is highly possible to do. But in the other hand, an issue found while describing the parameter of discontinuities condition on RMR. It is quite hard to interpret the condition of discontinuities when observable data are limited, for example when the available data is only from the core box. Thus, the objective of this research is to develop an alternative way in describing discontinuities condition, and then correlate the RMR and GSI vales and form it into model which solves the issue. The model formed shall consider the degree of accuracy and precision.

\section{Materials and methods}

\subsection{Geological condition}

Rock mass quality determination in the diversion tunnel of Meninting Dam was carried out through quantitative and qualitative observations on the rock samples acquired from drilling at 4 boreholes, as shown in the Fig. 2 below. The dataset from 4 boreholes consists of 205 subsurface rock samples that stored per meter in the core box.

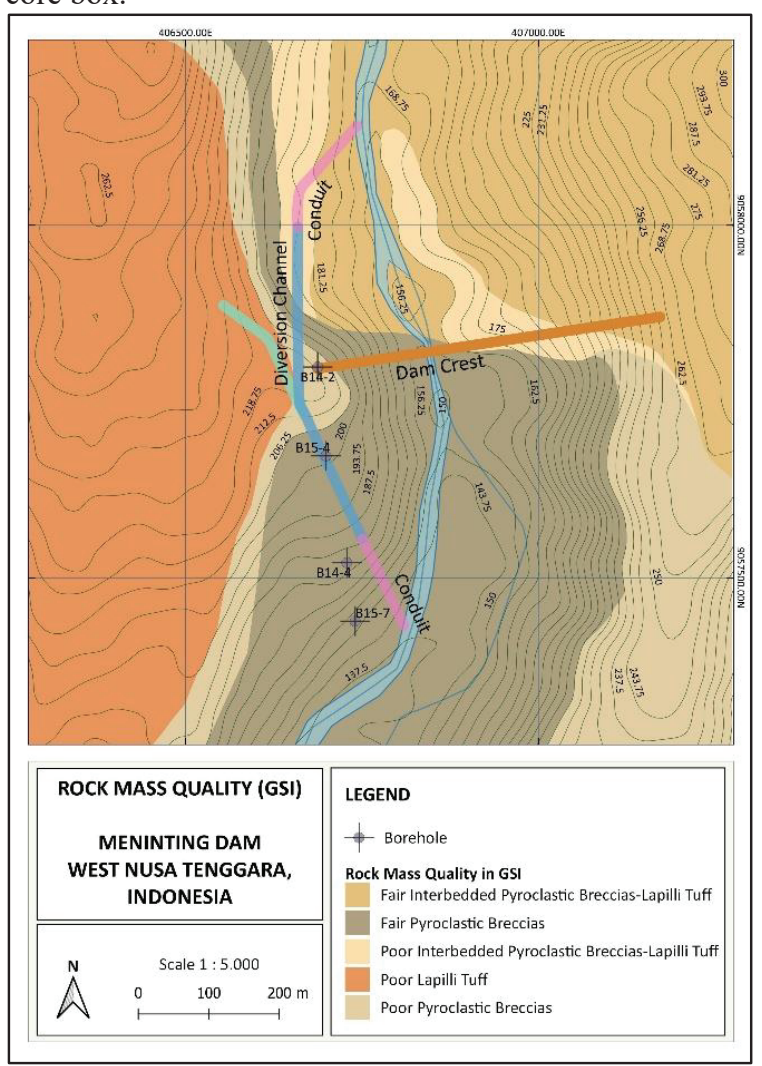

Fig. 2. Geological map and its rock mass quality using GSI method. 
Determination of rock mass quality using GSI was carried out by observing the rock structure in the core box and each surface condition. The rating of each parameter was given per meter. Measurements were also conducted to the rock samples which were more than 10 $\mathrm{cm}$ in length in a meter. The accounted data then used to summarize the percentage of RQD. Equation (4) below is used to calculate the final value of GSI, where $\mathrm{J}_{\text {cond }}$ is observation rating of joint condition.

$$
\mathrm{GSI}=1,5 \mathrm{~J}_{\text {cond }}+\mathrm{RQD} / 2
$$

Some values of the rock mass quality also determined by $\mathrm{RMR}_{89}$. Some samples are having whole parameters, especially when the boreholes position intersects with the face of excavation, in that term the facemapping can be conducted.

\subsection{Existing correlations}

By interpreting rock mass quality directly using $\mathrm{RMR}_{89}$ and GSI in the site with a comprehensive data available, the mathematical model can be drawn. That model describes the correlation between the value of both methods and can be used to predict the conversion between them in the future. However, limited data for determining the $\mathrm{RMR}_{89}$ value often causes the results to be less accurate and precise.

Meanwhile, GSI value that is obtained through visual observation considered to have higher degree of accuracy, it is because GSI can describe the actual conditions of a rock mass. Hence, many researchers had compiled many mathematical models which can describes the correlation of $\mathrm{RMR}_{89}$ and GSI. There are several mathematical models that have been developed to predict the value of $\mathrm{RMR}_{89}$ based on the value of GSI observed, some of them summarized below. Sequently from equation (1) to (3) is developed by Hoek Brown [6], Cosar [10], Singh and Tamrakar [11].

$$
\begin{gathered}
\mathrm{RMR}_{89}=\mathrm{GSI}+5 \\
\mathrm{RMR}_{89}=2.38 \mathrm{GSI}-54.93 \\
\mathrm{RMR}_{89}=1.36 \mathrm{GSI}+5.90
\end{gathered}
$$

In the other hand, rock mass quality determination using $\mathrm{RMR}_{89}$ considers the intact rock strength $\left(\mathrm{R}_{1}\right)$, rock mass structure $\left(\mathrm{R}_{2}\right.$ and $\left.\mathrm{R}_{3}\right)$, discontinuities condition $\left(R_{4}\right)$, and the presence of groundwater $\left(R_{5}\right)$ according to Table 1 . The orientation of discontinuities $\left(\mathrm{R}_{6}\right)$ was not considered because this parameter was not represented conceptually in GSI equation.

$\mathrm{R}_{1}$ was obtained through unconfined compressive testing, $\mathrm{R}_{2}$ and $\mathrm{R}_{3}$ could be obtained through the RQD and space of discontinuities, as well as the number of joints per meter as stated in $\mathrm{RMR}_{14}$ developed by Celada et al [12]. $\mathrm{R}_{4}$ could be obtained through surface interpretation on rock samples, while $\mathrm{R}_{5}$ is assumed to have a value of 15 , namely for dry rock mass.

\subsection{Calculation of Discontinuities Condition}

The problem which found while determining rock mass quality using $\mathrm{RMR}_{89}$ is the lack of precision in the observable data that related to discontinuities condition $\left(\mathrm{R}_{4}\right)$. In determining the weight for $\mathrm{R}_{4}$, there are several parameters that tend to have less precision when they were just observed through drilling rock samples, i.e., the length of each discontinuity (persistence) and their apertures. Obtaining those parameters just by observing the drilling rock samples did not represent its actual condition. Question about the precision of $\mathrm{R}_{4}$ became a dilemma then.

To answer the question above, it is necessary to make a correlation between the facemapping data observed from tunnel excavation and the interpretation of drilling rock samples. It becomes significant when the borehole intersects with excavation surface. The correlation between them both will produce more precise information. Frankly, the lack of boreholes makes this difficult to do. An alternative is needed to increase the degree of precision and the degree of confidence in the value of $\mathrm{R}_{4}$.

Meanwhile, GSI is obtained by visually observing the condition of rock structure that displayed on its surface, then it is namely Surface Condition Ratings (SCR). This parameter is closely related to the interpretation which carried out to produce $R_{4}$ in the RMR method. Zhang et al [13] compared the weights that used to determine $\mathrm{R}_{4}$ and SCR, as shown in the

\begin{tabular}{|c|c|c|c|c|}
\hline $\begin{array}{c}\text { Sub para- } \\
\text { meter }\end{array}$ & R4 (RMR89) & Rate & SCR (GSI) & Rate \\
\hline \multirow[t]{5}{*}{ Persistence } & $<1 \mathrm{~m}$ & 6 & - & - \\
\hline & $1-3 \mathrm{~m}$ & 4 & - & - \\
\hline & $3-10 \mathrm{~m}$ & 2 & - & - \\
\hline & $10-20 \mathrm{~m}$ & 1 & - & - \\
\hline & $>20 \mathrm{~m}$ & 0 & - & - \\
\hline \multirow[t]{5}{*}{ Aperture } & None & 6 & - & - \\
\hline & $<0.1 \mathrm{~mm}$ & 5 & - & - \\
\hline & $0.1-1 \mathrm{~mm}$ & 4 & - & - \\
\hline & $1-5 \mathrm{~mm}$ & 1 & - & - \\
\hline & $>5 \mathrm{~mm}$ & 0 & - & - \\
\hline \multirow[t]{5}{*}{ Roughness } & Very rough & 6 & Very rough & 6 \\
\hline & Rough & 5 & Rough & 5 \\
\hline & $\begin{array}{l}\text { Slightly } \\
\text { rough }\end{array}$ & 3 & Slightly rough & 3 \\
\hline & Smooth & 2 & Smooth & 1 \\
\hline & Very smooth & 0 & Very smooth & 0 \\
\hline \multirow[t]{4}{*}{ Infilling } & None & 6 & None & 6 \\
\hline & $\begin{array}{c}\text { Hard }<5 \\
\mathrm{~mm}\end{array}$ & 4 & Hard $<5 \mathrm{~mm}$ & 4 \\
\hline & $\begin{array}{c}\text { Hard }>5 \\
\mathrm{~mm}\end{array}$ & 2 & Hard $>5 \mathrm{~mm}$ & 2 \\
\hline & Soft $<5 \mathrm{~mm}$ & 2 & Soft $<5 \mathrm{~mm}$ & 2 \\
\hline
\end{tabular}
Table 3.

Table 3. Comparison of sub parameters between RMR89 and GSI to determine discontinuities condition. 


\begin{tabular}{|c|c|c|c|c|}
\hline $\begin{array}{c}\text { Sub para- } \\
\text { meter }\end{array}$ & R4 (RMR89) & Rate & SCR (GSI) & Rate \\
\hline & Soft $>5 \mathrm{~mm}$ & 0 & Soft $>5 \mathrm{~mm}$ & 0 \\
\hline \multirow[t]{5}{*}{$\begin{array}{l}\text { Weather- } \\
\text { ing }\end{array}$} & Unweathered & 6 & Unweathered & 6 \\
\hline & $\begin{array}{c}\text { Slightly } \\
\text { weathered }\end{array}$ & 5 & $\begin{array}{c}\text { Slightly } \\
\text { weathered }\end{array}$ & 5 \\
\hline & $\begin{array}{l}\text { Moderately } \\
\text { weathered }\end{array}$ & 3 & $\begin{array}{l}\text { Moderately } \\
\text { weathered }\end{array}$ & 3 \\
\hline & $\begin{array}{c}\text { Highly } \\
\text { weathered }\end{array}$ & 1 & $\begin{array}{c}\text { Highly } \\
\text { weathered }\end{array}$ & 1 \\
\hline & $\begin{array}{l}\text { Completely } \\
\text { weathered }\end{array}$ & 0 & $\begin{array}{l}\text { Completely } \\
\text { weathered }\end{array}$ & 0 \\
\hline
\end{tabular}

Based on the comparison in the Table 3, a mathematical model shall be generated. The first method in this research is to find an equation that able to predict the value of $\mathrm{R}_{4}$ using SCR value. In this work, there are several data that already have $\mathrm{R}_{4}$ value, and they are considered having a good precision. That dataset then being correlated with SCR value at the very similar locations. Correlating those data using mathematical method is adopted to generate the trendline and the equation. The result of the correlation is shown in the next chapter.

\subsection{Calculation of modified RMR and $\mathrm{RMR}_{89}$}

The second method in this research is finding the value of RMR. In this paper, RMR is divided into two, they are $\mathrm{RMR}_{89}$, which is based on observation data, and modified RMR, (then called $\mathrm{RMR}_{\mathrm{m} \text { ). }}$ The $\mathrm{RMR}_{\mathrm{m}}$ is the RMR that calculated differently using modified $\mathrm{R}_{4}$ that derived from the SCR according to the previous chapter. From that modification, the equation which going to be used to summarize $\mathrm{RMR}_{\mathrm{m}}$ is changed into the one below.

$$
\mathrm{RMR}_{\mathrm{m}}=\mathrm{R} 1+\mathrm{R} 2+\mathrm{R} 3+\text { modified } \mathrm{R} 4+\mathrm{R} 5
$$

\section{Results and Discussion}

This chapter shows some results, i.e., the value of discontinuities conditions, the value of $\mathrm{RMR}_{\mathrm{m}}$ and $\mathrm{RMR}_{89}$, and discusses about the degree of accuracy and its precision.

\subsection{The Generated Models}

Based on Fig. 3 below, the trendline is formed from those scattered points. The points are the data of $\mathrm{R}_{4}$ and SCR that were obtained from observation. A mathematical model can be generated as in the equation (6) below. Then this equation can be used to describe and calculate the value of discontinuities condition, when all the data that we have is Surface Condition Ratings (SCR) that was observed using GSI method. Then, the equation for $\mathrm{RMR}_{\mathrm{m}}$ is substituted into equation (7).

$$
\begin{gathered}
\mathrm{R}_{4}=1.0951 \mathrm{SCR}+10.328 \\
\mathrm{RMR}_{\mathrm{m}}=\mathrm{R} 1+\mathrm{R} 2+\mathrm{R} 3+1.0952 \mathrm{SCR}+ \\
10.328+\mathrm{R} 5
\end{gathered}
$$

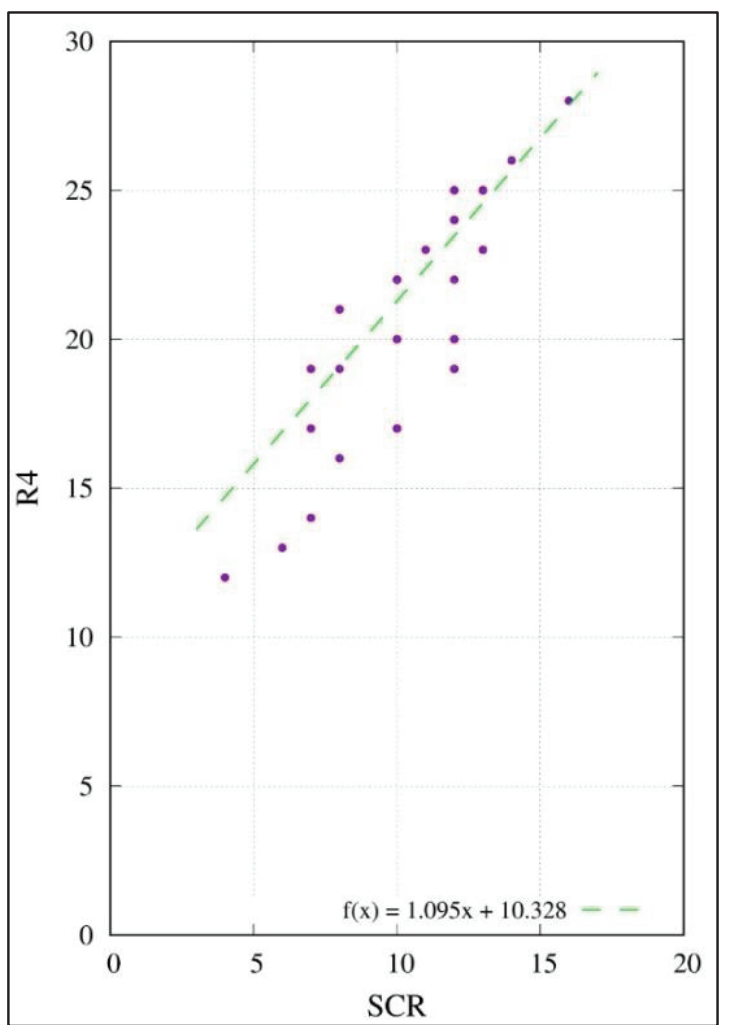

Fig. 3. Correlation between R4 (on RMR89) and SCR (on GSI).

After conducting some tests on that mathematical model, the data generated by the equation is presented in Fig. 4. The figure below displays some trendlines that drawn from the scattered of observation data using $\mathrm{RMR}_{89}$ and $\mathrm{RMR}_{\mathrm{m}}$. Both lines then visually compared to several trendlines from the equations that have been mentioned by other researchers, as shown in equation (1), (2), and (3).

In accordance with the distribution of data that observed using $\mathrm{RMR}_{89}$ and $\mathrm{RMR}_{\mathrm{m}}$, it shows that there are variances ranging from $0-5$ points. The differences come bolder on data with comprehensive information, especially mention to their persistence and aperture. Values of the observed data using $\mathrm{RMR}_{89}$ with comprehensive information available give a significantly different position on chart, while the observed data without comprehensive information available tend to be close to the value of $\mathrm{RMR}_{\mathrm{m}}$

From the information above, the relative position of observation data from $\mathrm{RMR}_{89}, \mathrm{RMR}_{\mathrm{m}}$, and their trendlines mean that they have a correlation. Mathematical models then be derived as shown in the equation (8) and (9) below.

$$
\begin{gathered}
\mathrm{RMR}_{89}=0.334 \mathrm{GSI}+38.78 \\
\mathrm{RMR}_{\mathrm{m}}=0.3497 \mathrm{GSI}+37.971
\end{gathered}
$$




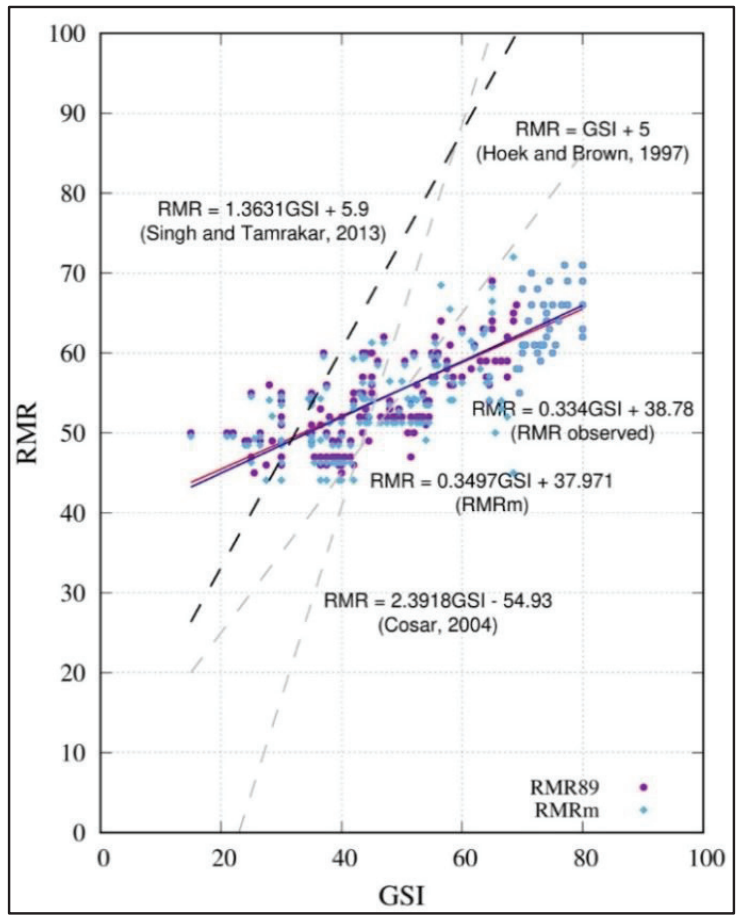

Fig. 4. Scattered data from observation using $\mathrm{RMR}_{89}$ and $\mathrm{RMR}_{\mathrm{m}}$

\subsection{Evaluation of the Precision and Accuracy}

Adjacency between $\mathrm{RMR}_{89}$ based on observation, $\mathrm{RMR}_{\mathrm{m}}$ based on observation, and the prediction generated from both equation model (8) and (9) are presented in Fig. 5. There is a significant difference in values between $\mathrm{RMR}_{89}$ based on observation and $\mathrm{RMR}_{\mathrm{m}}$ based on observation, while the predicted data have small differences in value.

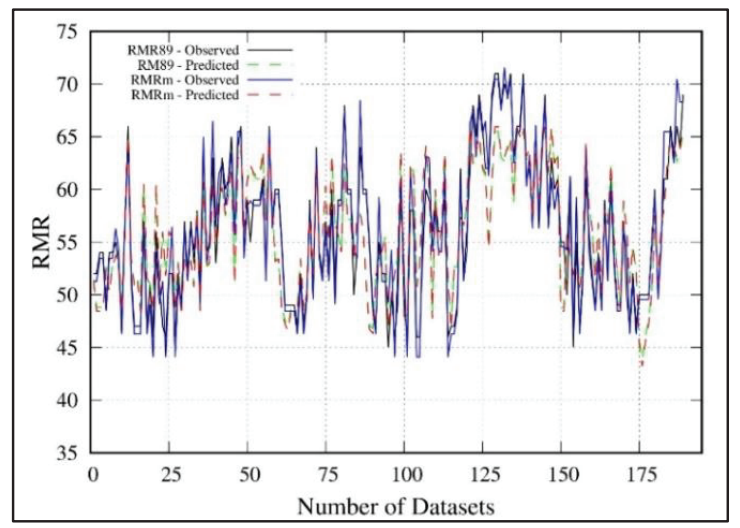

Fig. 5. Precision of observation data and predicted data, both using $\mathrm{RMR}_{89}$ and $\mathrm{RMR}_{\mathrm{m}}$

To ensure the degree of accuracy of both mathematical model (8) and (9), the MSE and RMSE ought to be calculated. The calculation is done by determining the relative comparison between the predicted values (both generated from $\mathrm{RMR}_{89}$ and $\mathrm{RMR}_{\mathrm{m}}$ ) and the $\mathrm{RMR}_{89}$ data based on observation.
$\mathrm{RMR}_{89}$ dataset that were obtained from observation are assumed to be the correct ones and being absolute.

Table 4. MSE and RMSE.

\begin{tabular}{lrr}
\hline Eq. & \multicolumn{1}{c}{ MSE } & \multicolumn{1}{c}{ RMSE } \\
\hline Hoek-Brown (1997) & 126,867 & 11,263 \\
Cosar (2004) & 1515,903 & 38,934 \\
Singh and Tamrakar (2013) & 1223,221 & 34,974 \\
RMR $_{89}$ & 14,164 & 3,763 \\
RMR $_{\mathrm{m}}$ & 14,232 & 3,772 \\
\hline
\end{tabular}

Table 4 above shows the degree of accuracy between the equation (8) and (9). Both mathematical models of $\mathrm{RMR}_{89}$ and $\mathrm{RMR}_{\mathrm{m}}$ are having the good accuracy, which is indicated by a small value in the RMSE. RMSE from those mathematical models, is also close to equation that developed by Hoek and Brown [3]. Fig. 6 below also shows the relationship between the error of the values generated by the $\mathrm{RMR}_{89}$ and $\mathrm{RMR}_{\mathrm{m}}$ mathematical models, the narrow gap between them means that both equations have similar accuracy.

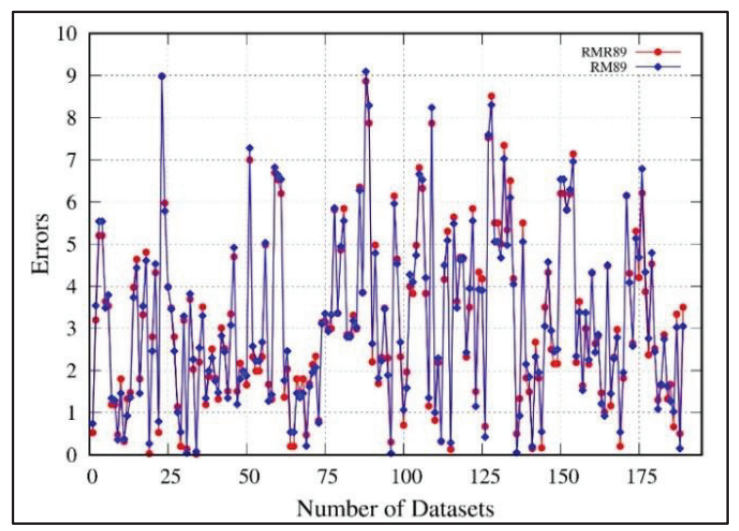

Fig. 6. Gap of error between $\mathrm{RMR}_{89}$ and $\mathrm{RMR}_{\mathrm{m}}$.

\section{Conclusions}

This study explains the correlation among some methods to determine rock mass quality. The methods used in this study are GSI, RMR 89 , and $\mathrm{RMR}_{\mathrm{m}}$, where $\mathrm{RMR}_{\mathrm{m}}$ is the $\mathrm{RMR}_{89}$ developed by Bienawski [4] with changes in $\mathrm{R}_{4}$ parameter. The modified $\mathrm{R}_{4}$ is calculated according to the weighting score of SCR (on the GSI). Through a series of experiments, the following conclusions are drawn below.

1. Based on 205 datasets of drilling rock samples and facemapping data, a series of observations can be conducted to determine rock quality based on the GSI and $\mathrm{RMR}_{89}$ method.

2. Due to limited information for compiling $R_{4}$ according to the rules developed by Bienawski [4], it can be solved by using an alternative equation to describe the discontinuities condition. $\mathrm{R} 4=$ 1.0951SCR + 10.328 can be applied, where SCR is the condition of discontinuities observed using the GSI's term. So that $\mathrm{RMR}_{\mathrm{m}}=\mathrm{R} 1+\mathrm{R} 2+\mathrm{R} 3+$ 
$1.0951 \mathrm{SCR}+10.328+\mathrm{R} 5$ is stated, and the values can be computed.

3. Based on the scatter chart of data that been observed using $\mathrm{RMR}_{89}$ and $\mathrm{RMR}_{\mathrm{m}}$, trendlines and mathematical models are derived. Both equations are $\mathrm{RMR}_{89}=0.334 \mathrm{GSI}+38.78$ and $\mathrm{RMR}_{\mathrm{m}}=0.3497 \mathrm{GSI}$ +37.971 , and they can be implemented to predict RMR value based on GSI data.

4. Two mathematical models above, can be applied to imply the correlation between RMR and GSI based on rock mass in the construction site of diversion tunnel of Meninting Dam. The RMR ${ }_{89}$ mathematical model will work effectively if comprehensive information about persistence, aperture, roughness, infilling, and weathering are available. Meanwhile, the mathematical model of $\mathrm{RMR}_{\mathrm{m}}$ can be an alternative equation when information about discontinuities condition is not thoroughly available.

5. Based on the evaluation of precision and accuracy, it can be stated that both mathematical models are having small gaps of error to each other as well as adjacency to $\mathrm{RMR}_{89}$ based on data observation and equation of $\mathrm{RMR}_{89}$ developed by Hoek and Brown [6].

6. In the near future, conversion from GSI to RMR, or vice versa, can be conducted with higher degree of accuracy. Those data then can be used for determining the excavation method, supporting, and the study of rock mass deformation precisely, especially in Meninting Dam.

The first author would like to thank to Ministry of Public Works and Housing for the full support of research funding through 2020 Super Specialist Scholarship Program, and the support from BWS Nusa Tenggara I for the permit to conduct this research are gratefully acknowledged.

\section{References}

1. S.A. Mangga, et al. Peta Geologi Regional Lembar Pulau Lombok, Nusa Tenggara Barat Skala $1: 250.000$ (2010)

2. Y. Wiyasri, Evaluasi Kondisi Geologi Teknik untuk Perencanaan Terowongan Saluran Penngelak Bendungan Meninting Lombok Barat. Master thesis. Gadjah Mada University, Indonesia (2020)

3. E. Hoek., E.T. Brown, J. Heuristics 16 (2), 167188. (1988)

4. Z.T. Bieniawski, Engineering Rock Mass Classifications: A Complete Manual for Engineers and Geologists in Mining, Civil and Petroleum Engineering (John. Wiley \& Sons, New York 1989)

5. E. Hoek, Strength of rock and rock masses. ISRM News J. 2 (2), 4-16 (1994)

6. E. Hoek, E.T. Brown, Int. J. Rock Mech. Min. Sci. Geomech. Abstr. 34, 1165-1186 (1997)

7. H. Sonmez, R. Ulusay, Int. J. Rock Mech. Min. Sci. 36 (6), 743-760 (1999)
8. H. Sonmez, R. Ulusay, Yerbilimleri 26, 77-99 (2002)

9. F. Ceballos et al, Relationship between RMRb and GSI based on in situ data, in ISRM European Rock Mechanics Symposium,Vigo (2014)

10. S. Coşar, Application of Rock Mass Classification Systems for Future Support Design of the Dim Tunnel Near Alanya. PhD thesis. Middle East Technical University, Turkey (2004)

11. J.L. Singh, N.K. Tamrakar, Bull. Dept. Geol. 16, 29-42 (2013)

12. B. Celada, I. Tardáguila, P. Varona, A. Rodríguez, Z.T. Bieniawski, Innovating tunnel design by an improved experience based RMR system, in World Tunnel Congress. Proceedings, Foz do Iguaçu, Brazil, 1-9 (2014)

13. Q. Zhang et al, Tunn. Undergr. Sp. Tech. 83, 7381 (2019) 